\title{
Acute Antiapoptotic Effects of Hydrocortisone in the Hippocampus of Neonatal Rats
}

\author{
P. N. MENSHANOV ${ }^{1,2}$, A. V. BANNOVA ${ }^{1}$, V. V. BULYGINA ${ }^{1}$, N. N. DYGALO ${ }^{1,3}$ \\ ${ }^{1}$ Functional Neurogenomics Laboratory, Institute of Cytology and Genetics, Russian Academy of \\ Science, Novosibirsk, Russian Federation, ${ }^{2}$ Institute of Economics and Industrial Engineering, \\ Russian Academy of Science, Novosibirsk, Russian Federation, ${ }^{3}$ Department of Natural Sciences, \\ Novosibirsk State University, Novosibirsk, Russian Federation
}

Received February 16, 2012

Accepted October 26, 2012

On-line December 13, 2012

\section{Summary}

Natural glucocorticoid hydrocortisone was suggested as a potent substitution for dexamethasone in the treatment of bronchopulmonary dysplasia in neonates. The aim of this study was to investigate whether hydrocortisone is able to affect the expression of apoptotic genes and the intensity of naturally occurring cell death in the developing rat hippocampus. Hormone treatment decreased procaspase- 3 and active caspase- 3 levels as well as DNA fragmentation intensity in the hippocampal formation of one-week-old rats in $6 \mathrm{~h}$ after injection. These changes were accompanied by an upregulation of antiapoptotic protein $\mathrm{BCl}-\mathrm{XL}$, while expression of proapoptotic protein Bax remained unchanged. The action of hydrocortisone was glucocorticoid receptor-independent, as the selective glucocorticoid receptor agonist dexamethasone did not affect either apoptotic protein levels or DNA fragmentation intensity in the hippocampal region. The data are the first evidences for in vivo antiapoptotic effects of hydrocortisone in the developing hippocampus.

\section{Key words}

Apoptosis - Developing hippocampus - Hydrocortisone • Glucocorticoids • DNA fragmentation • Caspase-3 • Bcl-XL • Bax

\section{Corresponding author}

P. N. Menshanov, Functional Neurogenomics Laboratory, Institute of Cytology and Genetics SB RAS, Lavrentyev av. 10, Novosibirsk, 630090, Russian Federation. Fax: +7-383-333-12-78. E-mail: eternity@bionet.nsc.ru, dxkorall@gmail.com

\section{Introduction}

The excess or deficit of glucocorticoids induces apoptosis in the adult hippocampus (Almeida et al. 2000, Greiner et al. 2001). This brain region is rich in both mineralocorticoid (MR) and glucocorticoid (GR) receptors that bind glucocorticoids through development (Diaz et al. 1998, Matthews 2000). A specific synthetic ligand of glucocorticoid receptor dexamethasone ameliorates neonatal hypoxic-ischemic injury of hippocampus and reduces the key marker of programmed cell death - DNA fragmentation in it (Ekert et al. 1997, Tuor 1997, Macaya et al. 1998, Felszeghy et al. 2004). This neuroprotective effect is beneficial for treatment of hypoxia-induced seizures in neonates, however, dexamethasone exposure was also known to decrease the volumes of hippocampus and brain gray matter as well as to induce behavioral deficits in the Morris water maze that result from hippocampal damage (Edwards and Burnham 2001, Ferguson et al. 2001, Jobe 2009). The side effects of dexamethasone treatment could be related either to so called "chemical adrenalectomy" that reduces availability of endogenous glucocorticoids for the brain or to direct induction of apoptosis by this drug (Meijer et al. 1998). It is well known that glucocorticoid depletion by surgical adrenalectomy induces apoptosis in the hippocampus of adult rats (Greiner et al. 2001). In neonates, dexamethasone treatment was also shown to increase a number of TUNEL-positive cells, a well-known marker of apoptosis, in the hippocampal formation 
(Crochemore et al. 2005, Duksal et al. 2009).

Unlike dexamethasone, natural glucocorticoid hydrocortisone is able to bind to both GR and MR (Rogalska 2010). Its low therapeutic doses do not provoke chemical adrenalectomy (Hopkins and Leinung 2005). Activation of MR by hydrocortisone may have prosurvival effect in hippocampal cells (Almeida et al. 2000). Up to date, there were no reports on the adverse neurological effects of hydrocortisone use for therapy of bronchopulmonary dysplasia in neonates, and this natural glucocorticoid was suggested as a potent substitution for dexamethasone in perinatology (Rademaker et al. 2008, Jobe 2009, Peltoniemi et al. 2009).

The neuroprotective as well as damaging effects of glucocorticoids may be related to the attenuation or augmentation respectively of naturally occurring cell death in the neonatal hippocampus. Apoptosis is much more active in the developing than in the adult rat brain (White and Barone 2001, Menshanov et al. 2006, Men'shanov et al. 2011), moreover, the maturity of the rat brain at postnatal day 8 (PD8) is grossly comparable to that of a late-term gestation human fetus or newborn infant (Edwards and Burnham 2001). Previous studies highlighted the importance of the mitochondrial apoptotic signaling cascade and its essential molecules - the antiapoptotic protein Bcl-XL, proapoptotic protein Bax and enzyme caspase-3 for naturally occurring cell death in the developing brain (Roth and D'Sa 2001). However, it is still unknown whether hydrocortisone is able to affect the expression of apoptotic genes as well as the intensity of naturally occurring cell death in the neonatal hippocampus. The aim of the study was to determine the acute effects of hydrocortisone on the expression of the apoptotic proteins and the intensity of DNA fragmentation in the hippocampus of one-week-old rats.

\section{Materials and Methods}

\section{Materials}

Polyclonal primary rabbit antibodies (P-19 antibody for Bax; S-18 for Bcl-XL; H-277 for intact and active caspase-3; I-19-R for actin) and secondary alkaline phosphatase conjugated goat anti-rabbit antibodies were purchased from Santa Cruz Biotechnology (Santa Cruz, CA, USA). Proteinase K was purchased from SibEnzyme (E347, Russia, Novosibirsk). Hydrocortisone was obtained from
Gedeon Richter AO (Hungary, Budapest, A73019A), dexamethasone was purchased from KRKA (Slovenia, Novo-Mesto, A49512). All other chemicals and reagents were of analytical grade and were purchased from Sigma Chemical Company (St. Louis, MO, USA) or Bio-Rad Laboratories (Hercules, CA, USA).

\section{Animals and treatment}

All animal procedures were in compliance with the European Communities Council Directive of 24 November 1986 (86/609/EEC) and were approved by the institutional Animal Care and Use Committee. All efforts were made to minimize animal suffering and to use only the number of animals necessary to produce reliable data. Wistar rat pups raised in the colony of our institute were used in experiments. The colony was maintained under natural illumination at $22-24{ }^{\circ} \mathrm{C}$ with food and water available ad libitum. The day of birth was considered as PD 1. Litters were culled to 8 pups on PD3. On PD8 animals were treated subcutaneously either with $5 \mathrm{mg} / \mathrm{kg}$ of hydrocortisone or $0.2 \mathrm{mg} / \mathrm{kg}$ of dexamethasone in $20 \mathrm{ul}$ of saline. Control animals received an equal volume of saline or remained intact. Rats were rapidly decapitated in 6 or $24 \mathrm{~h}$ after injection and hippocampi were dissected out on a cooled plate. Tissue samples were frozen in liquid nitrogen until further processing. Trunk blood was collected for determination of glucocorticoid levels by competitive protein-binding radioassay (Dygalo et al. 2006). 18-20 animals per experimental group were used for plasma glucocorticoid level assay; 4-8 rat pups per experimental group were used for mRNA, protein and DNA assays.

\section{mRNA level analysis}

Total cellular mRNA was isolated from the brain tissue by a single step acid guanidinium-phenolchloroform extraction method and converted to cDNA by reverse transcription. Semi-quantitative PCR was used to determine mRNA for apoptotic genes as it was described previously (Dygalo et al. 2004). Numbers of cycles and PCR parameters were optimized to obtain each primer-specific product within a linear range of amplification. Caspase-3 (5'-aagccg-aaactc-ttcatc-3' and 5'-tgagca-ttgaca-caatac-ac-3'), Bcl-XL (5'-gtgccatcaatg-gcaacc-cat-3' and 5'-ccgccg-ttctcc-tggatc-caa-3') and Bax (5'-tggttg-ccettt-tctact-ttg-3' and 5'-gaagtaggaaag-gaggcc-atc-3') mRNAs levels were normalized on the level of beta-actin mRNA (5'-cgtgaa-aagatc- 
acccag-at-3' and 5'-attgcc-gatagt-gatgac-ct-3') of the same cDNA sample.

\section{Immunoblot analysis}

Brain tissue was homogenized in lysis buffer containing $150 \mathrm{mM} \mathrm{NaCl}, 50 \mathrm{mM}$ Tris, $1 \%$ Triton $\mathrm{X}$ 100 and following protease inhibitors: $1 \mathrm{mM}$ phenylmethylsulfonylfluoride and $2 \mu \mathrm{g} / \mathrm{ml}$ of leupeptin, pepstatin and aprotinin. Electrophoresis was used to separate aliquots $(50 \mathrm{ug})$ of a total protein on $15 \%$ sodium dodecyl sulfate polyacrylamide gel. The resolved proteins were transferred on the nitrocellulose membrane by Transblot Cell (Bio-Rad Laboratories, USA). Ponceau $\mathrm{S}$ staining was used to control equal loading of the samples and protein transfer to membrane. Detection of apoptotic proteins was performed as it was described previously (Menshanov et al. 2006) with polyclonal primary rabbit antibodies (dilution 1:250 for Bax; 1:250 for Bcl-XL; 1:250 for intact and active caspase-3; 1:1000 for actin) and secondary alkaline phosphatase conjugated goat antirabbit antibody (1:500). Intensities of the signals for Bax, Bcl-XL, procaspase- 3 and active caspase- 3 bands were in a range of a linear dependence on these proteins amounts.

\section{DNA fragmentation analysis}

Brain tissue was homogenized in lysis buffer containing $100 \mathrm{mM} \mathrm{NaCl}, 20 \mathrm{mM}$ EDTA, $50 \mathrm{mM}$ Tris$\mathrm{HCl}(\mathrm{pH} 8.0)$ and $0.5 \%$ sodium dodecyl sulfate and incubated with $0.5 \mathrm{mg} / \mathrm{ml}$ proteinase $\mathrm{K}$ for $10 \mathrm{~h}$ at $55^{\circ} \mathrm{C}$. Total DNA was isolated from the tissue by phenol-chloroform extraction method, dissolved in TE buffer ( $\mathrm{pH}$ 7.5) and aliquots (2.5-4.5 $\mathrm{mkg}$ ) were separated on ethidium bromide stained $1.5 \%$ agarose gel for $90 \mathrm{~min}(4.5 \mathrm{~V} / \mathrm{cm})$ (Kalinina et al. 2002). High molecular DNA fraction (more then $50000 \mathrm{bp}$ ) and DNA fragments (180-3000 bp) were quantified by scanning densitometry (Biodoc System, Biometra $\mathrm{GmbH}$, Gottingen, Germany). Ratio of a sum of optical densities of the DNA fragments to the optical density of the high molecular DNA fraction of the same DNA sample (expressed as a percentage) was used as a DNA fragmentation index.

\section{Data analysis}

Data on concentration of glucocorticoids in blood plasma, relative levels of apoptotic proteins and mRNAs, as well as DNA fragmentation intensity were analyzed by one-way ANOVA (treatment factor). Statistical comparison of experimental groups was performed using Fisher LSD post-hoc test. The results were considered significant at probability level less than 0.05 .

\section{Results}

Hydrocortisone induced antiapoptotic changes in the developing rat hippocampus

Corticosterone levels in the plasma of untreated 8 -day-old rat pups were $12 \pm 1 \mathrm{ng} / \mathrm{ml}$, similar to basal levels of this hormone reported in previous studies (Jezova et al. 1998). The injection of hydrocortisone was followed by a subsequent rise of plasma glucocorticoid level $(54 \pm 11 \mathrm{ng} / \mathrm{ml}) 6 \mathrm{~h}$ after injection $\left(F_{(2,56)}=21.76, p<0.0001\right)$. Saline treatment also induced a slight increase in plasma glucocorticoid levels $(21 \pm 6$ $\mathrm{ng} / \mathrm{ml}$ ), which was insignificant and obviously accounted for endogenous glucocorticoid secretion caused by injection.

Hydrocortisone treatment was followed by upregulation of Bcl-XL expression. The levels of this antiapoptotic protein and its mRNA were significantly increased $6 \mathrm{~h}$ after hydrocortisone treatment (Fig. 1c,d; $\mathrm{F}_{(2,10)}=18.51, \mathrm{p}<0.001$ and Fig. 1a,b; $\mathrm{F}_{(2,20)}=4.10$, $\mathrm{p}<0.033$, respectively). The abundance of proapoptotic Bcl-2 family member Bax mRNA tended to decrease 6 $\mathrm{h}$ after hormone injection (Fig. 2a,b; $\mathrm{F}_{(2,15)}=3.20$, $\mathrm{p}<0.070$ ), and its protein level remained unaffected by treatment (Fig. 2c,d; $\mathrm{F}_{(2,16)}=0.01, \mathrm{p}>0.993$ ). Changes in the expression levels of Bcl-2 family members resulted in 1.5-fold increases in mRNA ratio of Bcl-XL to Bax as well as in ratio of these proteins $\left(\mathrm{F}_{(2,17)}=4.60\right.$, $\mathrm{p}<0.026$ and $\mathrm{F}_{(2,10)}=4.12, \mathrm{p}<0.05$, respectively).

Hormone-induced shift in Bcl-XL to Bax ratio towards antiapoptotic protein was accompanied by a decrease in the level of procaspase-3 (Fig. 3b,d; $\left.\mathrm{F}_{(2,11)}=7.44, \mathrm{p}<0.009\right)$. The level of the active form of this protease was also declined after hydrocortisone treatment (Fig. 3b,e; $F_{(2,9)}=5.37, p<0.030$ ). At the same time, the level of caspase-3 mRNA was unaffected by hormone (Fig. 3a,c; $\mathrm{F}_{(2,19)}=2.49$, p $>0.110$ ).

The intensity of DNA fragmentation determined by gel-electrophoresis was slightly but nevertheless significantly attenuated by hydrocortisone in the hippocampal formation of 8-day-old rats $6 \mathrm{~h}$ after injection (Fig. 4; $\mathrm{F}_{(3,16)}=3.34, \mathrm{p}<0.046$ ). 
a

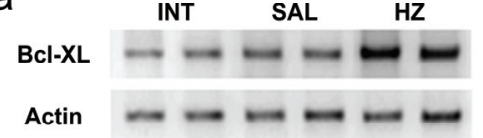

b

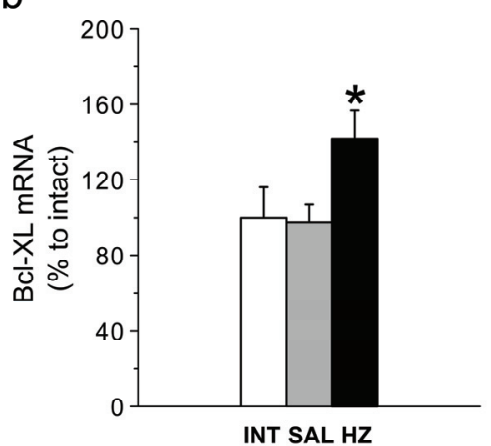

a

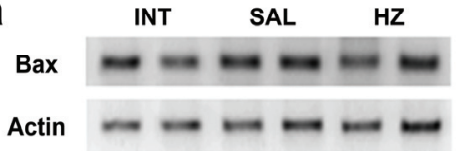

b
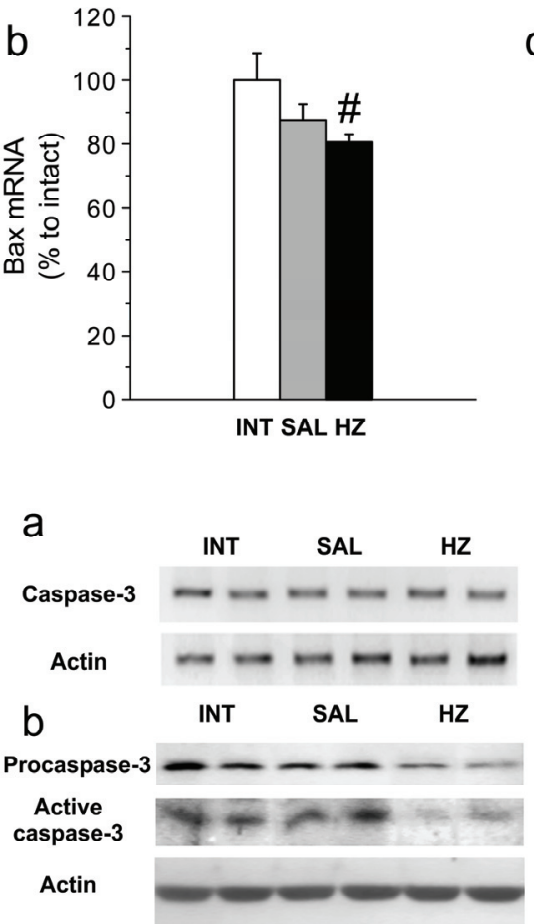

d

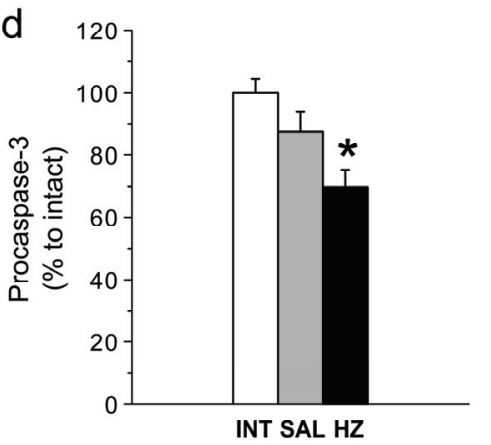

C

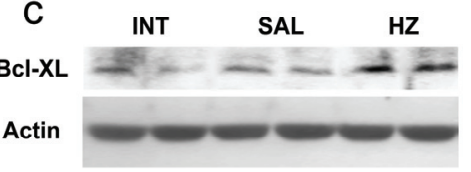

d

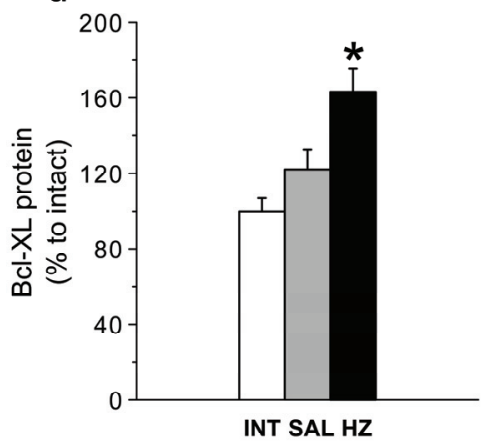

C
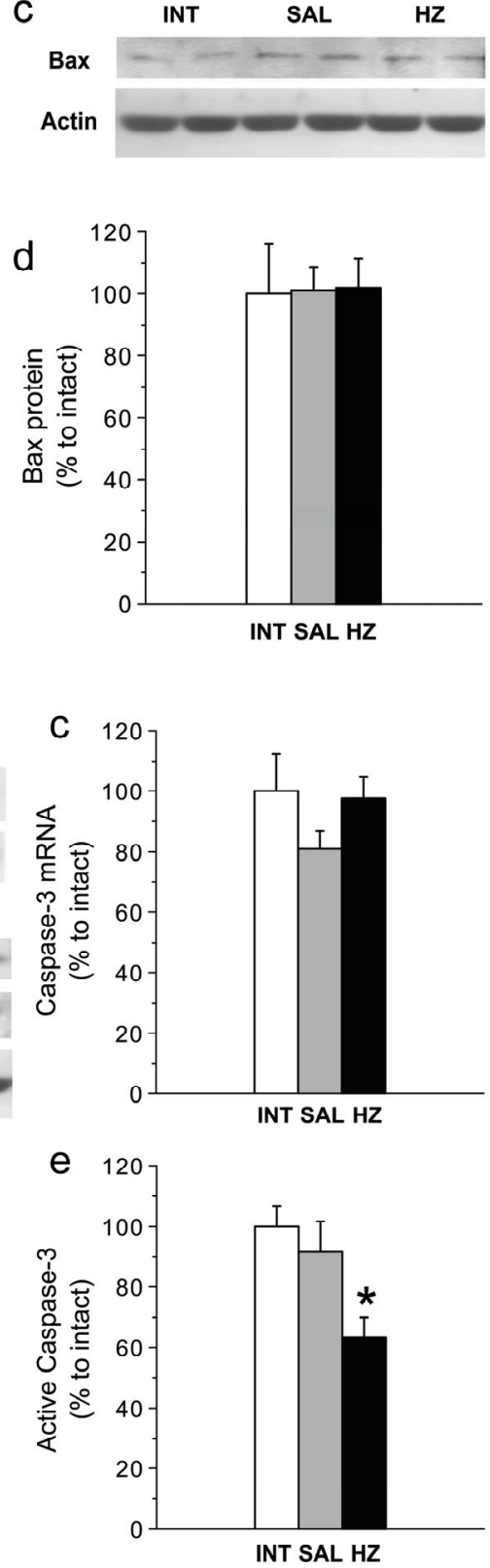

Fig. 1. BCl-XL expression in the hippocampi of 8-day-old rats $6 \mathrm{~h}$ after hydrocortisone administration. (a) Electrophoresis of $\mathrm{Bcl}-\mathrm{XL}$ and beta-actin RT-PCR products on $1.5 \%$ agarose gel. (b) $\mathrm{Bcl}-\mathrm{XL}$ mRNA levels. (c) Immunoblot with $\mathrm{Bcl}-\mathrm{XL}$ and actin bands. (d) Bcl-XL protein levels. * $-\mathrm{p}<0.05$ vs other groups. INT - intact group, $\mathrm{SAL}$ - saline-treated group, $\mathrm{HZ}$ - hydrocortisonetreated group. Data are presented as the means \pm SEM.

Fig. 2. Bax expression in the hippocampi of 8-dayold rats $6 \mathrm{~h}$ after hydrocortisone administration. (a) Electrophoresis of Bax and beta-actin RT-PCR products on $1.5 \%$ agarose gel. (b) Bax mRNA levels. (c) Immunoblot with Bax and actin bands. (d) Bax protein levels. \# $-p<0.1$ vs intact group. INT - intact group, SAL - saline-treated group, $\mathrm{HZ}$ - hydrocortisone-treated group. Data are presented as the means \pm SEM.

Fig. 3. Caspase- 3 expression in the hippocampi of 8-day-old rats $6 \mathrm{~h}$ after hydrocortisone administration. (a) Electrophoresis of caspase-3 and beta-actin RT-PCR products on $1.5 \%$ agarose gel. (b) Immunoblot with procaspase-3, active caspase-3 and actin bands. (c) Caspase-3 mRNA levels. (d) Procaspase-3 protein levels. (e) Active caspase-3 protein levels. $*-p<0.05$ vs other groups. INT - intact group, SAL - saline-treated group, HZ - hydrocortisone-treated group. Data are presented as the means \pm SEM. 


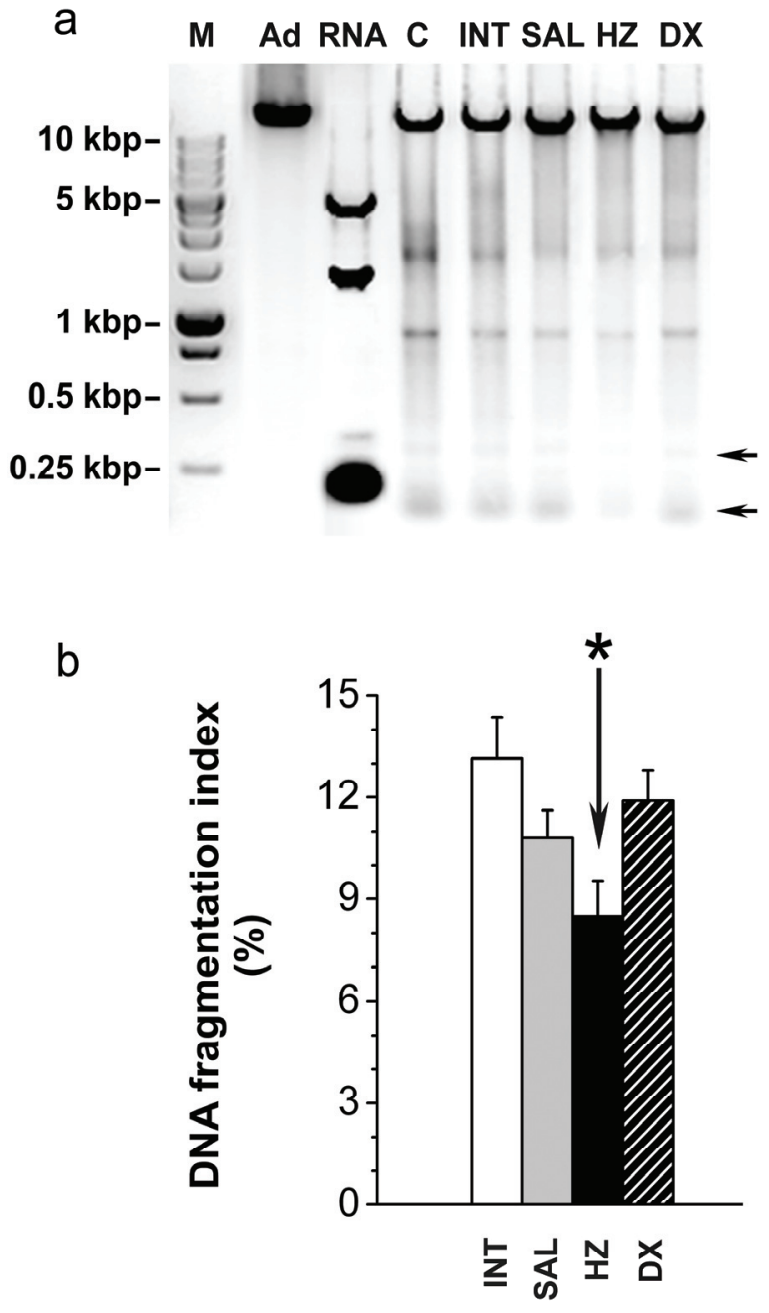

Fig. 4. DNA fragmentation in the hippocampi of 8-day old rats $6 \mathrm{~h}$ after hydrocortisone and dexamethasone administration. (a) Electrophoresis of total DNA and control samples on $1.5 \%$ agarose gel revealed high molecular DNA fraction and DNA fragments (180-3000 bp) in the samples derived from the developing hippocampus. (b) DNA fragmentation index. M marker of fragments length (1 Kbp), Ad - total DNA control sample derived from the hippocampus of adult rat, RNA - total RNA control sample derived from the hippocampus of PD8 rats, $\mathrm{C}$ - total DNA control sample derived from the neocortex of PD8 rat, INT - intact group, SAL - saline-treated group, HZ hydrocortisone-treated group, DX - dexamethasone-treated group. Data are presented as the means \pm SEM. Arrows mark the position of low-molecular apoptotic DNA fragments (180$200 \mathrm{bp}$ and $360-400 \mathrm{bp}$ ) on gel. * $-\mathrm{p}<0.05$ vs intact and DX group.

Dexamethasone did not affect the expression of apoptotic proteins $6 \mathrm{~h}$ after injection

To check whether the hydrocortisone actions were GR- and/or MR-dependent, the PD8 rats were treated either with hydrocortisone or a single equivalent dose of pure GR agonist dexamethasone. Dexamethasone treatment did not induce any changes in the protein levels of either Bcl-XL or Bax $6 \mathrm{~h}$ after injection, while Bcl-XL protein level was increased again by hydrocortisone treatment (Fig. 5a; $\mathrm{F}_{(3,18)}=5.93, \mathrm{p}<0.0054$ for Bcl-XL; Fig. $5 b ; \mathrm{F}_{(3,22)}=0.59, \mathrm{p}>0.628$ for Bax). Similarly, the protein levels of procaspase-3 and its active form were affected only by hydrocortisone, but not by synthetic GR agonist (Fig. $5 \mathrm{c} ; \mathrm{F}_{(3,18)}=3.27, \mathrm{p}<0.046$ for procaspase-3; Fig. $5 \mathrm{~d} ; \mathrm{F}_{(3,18)}=3.70, \mathrm{p}<0.031$ for active caspase-3). Dexamethasone also failed to affect the intensity of DNA fragmentation in the developing hippocampus (Fig. 4). Thus, the administration of the GR agonist did not cause the antiapoptotic changes at all.

Glucocorticoids did not affect the expression of apoptotic proteins 24 h after injection

The analysis of protein levels was performed $24 \mathrm{~h}$ after injection to find out whether the antiapoptotic changes were continuous or reversed by delayed cell death activation. However, neither hydrocortisone nor dexamethasone affected the levels of Bcl-XL, Bax, procaspase- 3 and active caspase- 3 in the hippocampi of rats $24 \mathrm{~h}$ after injection (Fig. 5a-d; $\mathrm{F}_{(3,18)}=0.05, \mathrm{p}>0.982$ for Bcl-XL; $\mathrm{F}_{(3,18)}=0.26, \mathrm{p}>0.850$ for $\mathrm{Bax} ; \mathrm{F}_{(3,18)}=0.34$, $p>0.794$ for procaspase- $3 ; F_{(3,18)}=0.67, p>0.582$ for active caspase-3).

\section{Discussion}

The present findings show that hydrocortisone is capable of inducing acute antiapoptotic alterations in gene expression in the developing hippocampus. In our study, antiapoptotic effects were found after injection of $5 \mathrm{mg} / \mathrm{kg}$ of the hormone. This dose of hydrocortisone is rather low, corresponds to the typical doses of glucocorticoids used in the treatment of postnatal bronchopulmonary dysplasia (Watterberg 2007, Rademaker et al. 2008, Jobe 2009) and was able to upregulate the plasma glucocorticoid level. However, antiapoptotic changes were not observed after treatment with the equivalent dose of GR agonist dexamethasone, revealing the GR-independent nature of hormone action. It is likely that the observed hydrocortisone-induced changes depended on the activation of MR, similar to the antiapoptotic MR-dependent action of natural glucocorticoids in the adult hippocampus (Almeida et al. 2000, Rogalska 2010), as the hippocampal levels of this type of receptors were already high on PD7-8 (Edwards and Burnham 2001). 

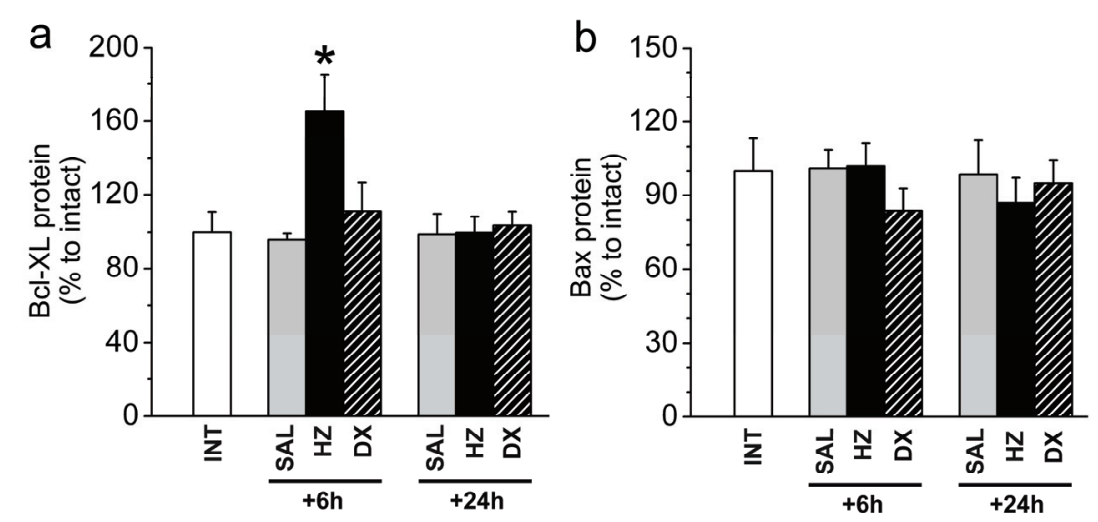

Fig. 5. Dynamics of expression of apoptotic proteins in the hippocampi of neonatal rats after hydrocortisone and dexamethasone administration 6 and $24 \mathrm{~h}$ after injection. (a) $\mathrm{Bcl}-\mathrm{XL}$ protein levels. (b) Bax protein levels. (c) Procaspase-3 protein levels. (d) Active caspase-3 protein levels. $*-p<0.05$ vs other groups. INT - intact group, SAL saline-treated group, $\mathrm{HZ}$ - hydrocortisonetreated group, DX - dexamethasone-treated group. Data are presented as the means \pm SEM.
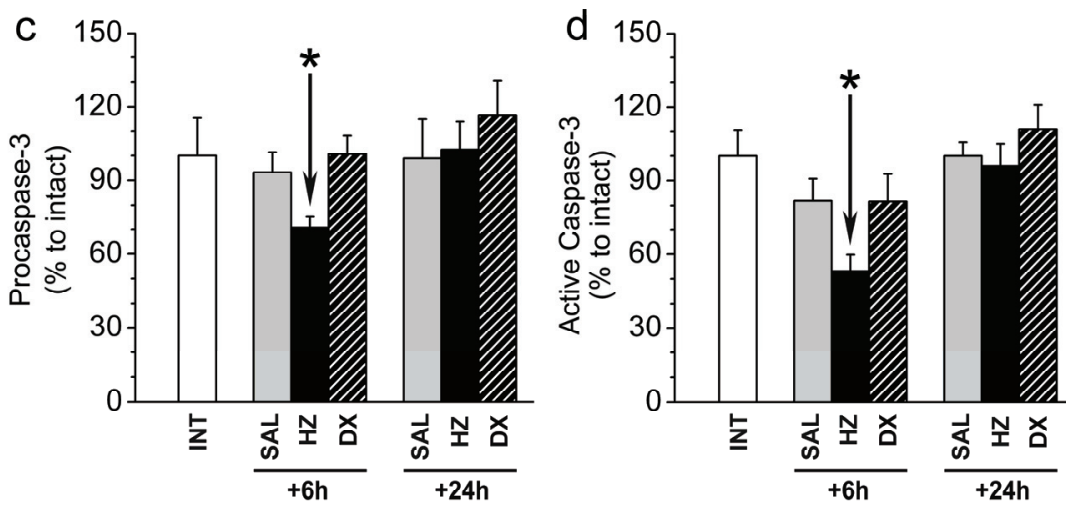

Hydrocortisone treatment increased mRNA and protein levels of Bcl-XL in the hippocampal region of neonatal rats in our study. The observed upregulation of Bcl-XL expression could result from activation of $\mathrm{P} 4$ and, possibly, P3 distal promoters of Bcl-X gene by MR. P4 and P3 promoters contain specific glucocorticoidresponse elements, and binding of ligand-activated receptors to these elements induces Bcl-XL expression both in vitro and in vivo (Gascoyne et al. 2003, Viegas et al. 2004). It is also known that overexpression of Bcl-XL prevents the activation of caspase-3 (Granville et al. 1998) and Bax-mediated cell death (He et al. 2003) as well as apoptosis induced by hypoxia-ischemia in the neonatal brain (Parsadanian et al. 1998). Thus, the upregulation of Bcl-XL would be expected to decrease susceptibility of hippocampal cells to apoptosis in the absence of the increase in Bax expression (Bannova et al. 2005).

Indeed, the shift in the Bcl-XL to Bax ratio towards antiapoptotic protein expression was associated with the changes in the downstream apoptotic events in our experiments. Caspase- 3 is the main apoptotic effector enzyme in the developing brain, and its downregulation or inhibition attenuates programmed cell death (Kalinina et al. 2001, Cheng et al. 2008). Hydrocortisone decreased the levels of procaspase- 3 and active caspase- 3 proteins in the neonatal hippocampus in our study. Moreover, hormone-induced downregulation of active caspase-3 level was in parallel with the change in the quantity of DNA fragments. DNA fragments considered to be a specific and definite hallmark of apoptosis, as they present in the tissue for a rather long period of time, at least for hours, after cell death induction (MoritaFujimura et al. 1999, Galluzzi et al. 2009). Thus, the parallel attenuation of both active caspase-3 levels and levels of DNA fragmentation suggested real antiapoptotic effects of hydrocortisone in the neonatal hippocampus.

As there were no differences in the abundance of caspase- 3 mRNA, the decrease in the levels of pro- and active caspase-3 was most likely accounted for accelerated degradation of this enzyme induced by hydrocortisone. This suggestion is supported by procaspase- 3 half-life length, which is about $5 \mathrm{~h}$ and could be even shorten by specific ubiquitin ligases, and also by well known facts that glucocorticoids inhibit protein synthesis and accelerate protein catabolism (Tan et al. 2006).

It looks like the antiapoptotic protein Bcl-XL was the possible target of hydrocortisone. Neonatal hippocampus is not an exclusive example of such glucocorticoid action. It was shown that these hormones are capable of inhibiting apoptosis in cells of different types via induction of Bcl-XL expression (Chonghaile et al. 2006, Petrella et al. 2006). Antiapoptotic action of 
glucocorticoids may be an underlying mechanism of developing brain protection from hypoxic-ischemic injury by these hormones, which was found in previous studies (Ekert et al. 1997, Tuor 1997, Macaya et al. 1998, Felszeghy et al. 2004). In these experiments glucocorticoid treatment was most effective when applied 5-6 h before hypoxia-ischemia (Tuor 1997, Macaya et al. 1998), and in the present study Bcl-XL expression was also found to be increased in the hippocampal tissue within this time interval after hormone treatment.

It also should be noted that the administration of the single equivalent dose of dexamethasone on PD8 failed to induce any significant proapoptotic changes in the levels of hippocampal apoptotic proteins. As the proapoptotic effects of glucocorticoids are usually explained by GR activation (Almeida et al. 2000, Rogalska 2010), the absence of such changes in our experiment might be a simple reflection of the developmental dynamics of hippocampal levels of GR which are poorly expressed in this whole brain region (only in several cell populations) until the third-fourth week after birth (Edwards and Burnham 2001). Moreover, our results were in agreement with the fact that the hippocampus of juvenile rats is much less susceptible to the dexamethasone-mediated damage than the adult one (Hassan et al. 1996).

In summary, our data provide the first evidence that hydrocortisone induces short-term antiapoptotic changes in the developing hippocampus. This antiapoptotic ability of natural glucocorticoid might be used in perinatal medicine for the brain protection, however, it should be cautioned that "antiapoptotic" is not a synonym for "neuroprotective", especially in the case of the possible overinhibition of naturally occurring cell death in the developing brain. Further studies are necessary to clarify whether hydrocortisone-induced antiapoptotic effects might be beneficial or deleterious for morphological and functional development of the hippocampus.

\section{Conflict of Interest}

There is no conflict of interest.

\section{Acknowledgements}

This study was supported by RFBR grant 12-04-01069, 12-04-31081-mol_a, 12-04-33110-mol_a_ved and RF MES program № 8060 .

\section{References}

ALMEIDA OF, CONDE GL, CROCHEMORE C, DEMENEIX BA, FISCHER D, HASSAN AH, MEYER M, HOLSBOER F, MICHAELIDIS TM: Subtle shifts in the ratio between pro- and antiapoptotic molecules after activation of corticosteroid receptors decide neuronal fate. FASEB $J$ 14: 779-790, 2000.

BANNOVA AV, MEN'SHANOV PN, IL'INYKH FA, KALININA TS, DYGALO NN: Bax and Bcl-XL apoptosis protein mRNA in rat brain stem and cortex during ontogeny. Bull Exp Biol Med 139: 700-702, 2005.

CHENG G, ZHU L, MAHATO RI: Caspase-3 gene silencing for inhibiting apoptosis in insulinoma cells and human islets. Mol Pharm 5: 1093-1102, 2008.

CHONGHAILE TN, CONCANNON CG, SZEGEZDI E, GORMAN AM, SAMALI A: Dexamethasone inhibits apoptosis in C6 glioma cells through increased expression of Bcl-XL. Apoptosis 11: 1247-1255, 2006.

CROCHEMORE C, LU J, WU Y, LIPOSITS Z, SOUSA N, HOLSBOER F, ALMEIDA OFX: Direct targeting of hippocampal neurons for apoptosis by glucocorticoids is reversible by mineralocorticoid receptor activation. Mol Psychiatry 10: 790-798, 2005.

DIAZ R, BROWN RW, SECKL JR: Distinct ontogeny of glucocorticoid and mineralocorticoid receptor and 11 betahydroxysteroid dehydrogenase types I and II mRNAs in the fetal rat brain suggest a complex control of glucocorticoid actions. J Neurosci 18: 2570-2580, 1998.

DUKSAL F, KILIC I, TUFAN AC, AKDOGAN I: Effects of different corticosteroids on the brain weight and hippocampal neuronal loss in rats. Brain Res 1250: 75-80, 2009.

DYGALO NN, BANNOVA AV, KALININA TS, SHISHKINA GT: Clonidine increases caspase-3 mRNA level and DNA fragmentation in the developing rat brainstem. Dev Brain Res 152: 225-231, 2004.

DYGALO NN, SHISHKINA GT, KALININA TS, YUDINA AM, OVCHINNIKOVA ES: Effect of repeated treatment with fluoxetine on tryptophan hydroxylase-2 gene expression in the rat brainstem. Pharmacol Biochem Behav 85: 220-227, 2006. 
EDWARDS HE, BURNHAM WM: The impact of corticosteroids on the developing animal. Pediatr Res 50: 433-440, 2001.

EKERT P, MACLUSKY N, LUO XP, LEHOTAY DC, SMITH B, POST M, TANSWELL AK: Dexamethasone prevents apoptosis in a neonatal rat model of hypoxic-ischemic encephalopathy (HIE) by a reactive oxygen species-independent mechanism. Brain Res 747: 9-17, 1997.

FELSZEGHY K, BANISADR G, ROSTENE W, NYAKAS C, HAOUR F: Dexamethasone downregulates chemokine receptor CXCR4 and exerts neuroprotection against hypoxia/ischemia-induced brain injury in neonatal rats. Neuroimmunomodulation 11: 404-413, 2004.

FERGUSON SA, PAULE MG, HOLSON RR: Neonatal dexamethasone on Day 7 in rats causes behavioral alterations reflective of hippocampal, but not cerebellar, deficits. Neurotoxicol Teratol 23: 57-69, 2001.

GALLUZZI L, AARONSON SA, ABRAMS J, ALNEMRI ES, ANDREWS DW, BAEHRECKE EH, ET AL.: Guidelines for the use and interpretation of assays for monitoring cell death in higher eukaryotes. Cell Death Differ 16: 1093-1107, 2009.

GASCOYNE DM, KYPTA RM, VIVANCO MM: Glucocorticoids inhibit apoptosis during fibrosarcoma development by transcriptionally activating Bcl-xL. J Biol Chem 278: 18022-18029, 2003.

GRANVILLE DJ, JIANG H, AN MT, LEVY JG, MCMANUS BM, HUNT DW: Overexpression of Bcl-X(L) prevents caspase-3-mediated activation of DNA fragmentation factor (DFF) produced by treatment with the photochemotherapeutic agent BPD-MA. FEBS Lett 422: 151-154, 1998.

GREINER M, CARDENAS S, PARRA C, BRAVO J, AVALOS AM, PAREDES A, LARA HE, FIEDLER JL: Adrenalectomy regulates apoptotic-associated genes in rat hippocampus. Endocrine 15: 323-333, 2001.

HASSAN AHS, VON ROSENSTIEL P, PATCHEV VK, HOLSBOER F, ALMEIDA OFX: Exacerbation of apoptosis in the dentate gyrus of the aged rat by dexamethasone and the protective role of corticosterone. Exp Neurology 140: 43-52, 1996.

HE L, PERKINS GA, POBLENZ AT, HARRIS JB, HUNG M, ELLISMAN MH, FOX DA: Bcl-xL overexpression blocks bax-mediated mitochondrial contact site formation and apoptosis in rod photoreceptors of lead-exposed mice. Proc Natl Acad Sci USA 100: 1022-1027, 2003.

HOPKINS RL, LEINUNG MC: Exogenous Cushing's syndrome and glucocorticoid withdrawal. Endocrinol Metab Clin N Am 34: 371-384, 2005.

JEZOVA D, KISS A, TOKAREV D, SKULTETYOVA I: Stress hormone release and proopiomelanocortin mRNA levels in neonatal rats treated with monosodium glutamate to induce neurotoxic lesions. Stress Medicine 14: 255-260, 1998.

JOBE AH: Postnatal corticosteroids for bronchopulmonary dysplasia. Clin Perinatol 36: 177-188, 2009.

KALININA TS, BANNOVA AV, DYGALO NN: Content of apoptotic enzyme caspase-3 mRNA in brain stem and cortex in rats during postnatal ontogeny. Bull Exp Biol Med 132: 748-750, 2001.

KALININA TS, BANNOVA AV, DYGALO NN: Quantitative evaluation of DNA fragmentation. Bull Exp Biol Med 134: 554-556, 2002.

MACAYA A, MUNELL F, FERRER I, DE TORRES C, REVENTOS J: Cell death and associated c-jun induction in perinatal hypoxia-ischemia. Effect of the neuroprotective drug dexamethasone. Mol Brain Res 56: 29-37, 1998.

MATTHEWS SG: Antenatal glucocorticoids and programming of the developing CNS. Pediatr Res 47: 291-300, 2000.

MEIJER OC, DE LANGE EC, BREIMER DD, DE BOER AG, WORKEL JO, DE KLOET ER: Penetration of dexamethasone into brain glucocorticoid targets is enhanced in mdr1A P-glycoprotein knockout mice. Endocrinology 139: 1789-1793, 1998.

MEN'SHANOV PN, MUZYKA VV, DYGALO NN: Coordinated expression of pro- and antiapoptotic proteins in the hippocampus of neonatal rats. Neurochem $J$ 5: 20-23, 2011.

MENSHANOV PN, BANNOVA AV, DYGALO NN: Region-specific interrelations between apoptotic proteins expression and DNA fragmentation in the neonatal rat brain. Neurochem Res 31: 869-875, 2006.

MORITA-FUJIMURA Y, FUJIMURA M, KAWASE M, CHEN SF, CHAN PH: Release of mitochondrial cytochrome $\mathrm{c}$ and DNA fragmentation after cold injury-induced brain trauma in mice: possible role in neuronal apoptosis. Neurosci Lett 267: 201-205, 1999. 
PARSADANIAN AS, CHENG Y, KELLER-PECK CR, HOLTZMAN DM, SNIDER WD: Bcl-xL is an antiapoptotic regulator for postnatal CNS neurons. J Neurosci 18: 1009-1019, 1998.

PELTONIEMI OM, LANO A, PUOSI R, YLIHERVA A, BONSANTE F, KARI MA, HALLMAN M: Trial of early neonatal hydrocortisone: two-year follow-up. Neonatology 95: 240-247, 2009.

PETRELLA A, ERCOLINO SF, FESTA M, GENTILELLA A, TOSCO A, CONZEN SD, PARENTE L: Dexamethasone inhibits TRAIL-induced apoptosis of thyroid cancer cells via Bcl-xL induction. Eur J Cancer 42: 3287-3293, 2006.

RADEMAKER KJ, DE VRIES LS, UITERWAAL CS, GROENENDAAL F, GROBBEE DE, VAN BEL F: Postnatal hydrocortisone treatment for chronic lung disease in the preterm newborn and long-term neurodevelopmental follow-up. Arch Dis Child Fetal Neonatal Ed 93: F58-F63, 2008.

ROGALSKA J: Mineralocorticoid and glucocorticoid receptors in hippocampus: Their impact on neurons survival and behavioral impairment after neonatal brain injury. Vitamin Hormon 82: 391-419, 2010.

ROTH KA, D'SA C: Apoptosis and brain development. Ment Retard Dev Disabil Res Rev 7: 261-266, 2001.

TAN M, GALLEGOS JR, GU Q, HUANG Y, LI J, JIN Y, LU H, SUN Y: SAG/ROC-SCF beta-TrCP E3 ubiquitin ligase promotes pro-caspase-3 degradation as a mechanism of apoptosis protection. Neoplasia 8: 1042-1054, 2006.

TUOR UI: Glucocorticoids and the prevention of hypoxic-ischemic brain damage. Neurosci Biobehav Rev 21: 175-179, 1997.

VIEGAS LR, VICENT GP, BARANAO JL, BEATO M, PECCI A: Steroid hormones induce bcl-X gene expression through direct activation of distal promoter P4. J Biol Chem 279: 9831-9839, 2004.

WATTERBERG KL: Postnatal steroids for bronchopulmonary dysplasia: where are we now? J Pediatr 150: 327-328, 2007.

WHITE LD, BARONE S JR: Qualitative and quantitative estimates of apoptosis from birth to senescence in the rat brain. Cell Death Differ 8: 345-356, 2001.

YU S, PATCHEV AV, WU Y, LU J, HOLSBOER F, ZHANG J-Z, SOUSA N, ALMEIDA OFX: Depletion of the neural precursor cell pool by glucocorticoids. Ann Neurol 67: 21-30, 2010. 